\title{
Tujuan Penggunaan Internet Pada Penduduk Berumur 5 Tahun Ke Atas Menurut Kabupaten/Kota di Provinsi Kepulauan Riau
}

\author{
BETI \\ Badan Pusat Statistik Kepulauan Riau, Jl. Ahmad Yani No.21, Tanjungpinang \\ email: beti2@bps.go.id
}

\begin{abstract}
ABSTRAK
Penyediaan akses dan sarana internet bertujuan untuk meningkatkan produktivitas masyarakat terutama dalam hal perekonomian. Kehadiran internet belum tentu dapat dimanfaatkan sebagai mana mestinya. Secara kasat mata intenet yang digunakan di Kabupaten /Kota di Provinsi Kepulauan Riau masih sebatas media hiburan seperti sebagai media sosial Facebook, Twitter, Instagram dan lainnya. Sementara itu amat sangat disayangkan ketersediaan media internet tidak dimanfaatkan secara optimal. Untuk melihat apakah ada tujuan lain penduduk berumur 5 tahun ke atas yang menggunakan internet selain sebagai media sosial maka dilakukan penelitian ini. Dari penelitian ini didapatkan memang sebagian besar masyarakat menggunakan internet hanya sebagai media sosial. Penggunaan sebagai penunjang kehidupan perekonomian hanya menempati urutan ke 6 dari 8 tujuan penggunaan internet. Jadi dapat disimpulkan tujuan penggunaan internet belum maksimal dan perlu peran pemerintah daerah untuk membantu mensosialisaikan manfaat yang bisa diambil dari keberadaan akses internet di daerahnya masing-masing, terutama manfaat untuk menunjang kebutuhan ekonomi rumah tangga.
\end{abstract}

Kata Kunci: akses internet, lima tahun, teknologi informasi, susenas

\begin{abstract}
The provision of internet access and facilities is aimed at increasing community productivity, especially in terms of the economy. The presence of the internet may not necessarily be used as it should. In plain view the internet used in Regencies / Cities in Riau Islands Province is still limited to entertainment media such as social media Facebook, Twitter, Instagram and others. Meanwhile it is very unfortunate that the availability of internet media is not utilized optimally. To see if there are other objectives of residents aged 5 years and over who use the internet other than as social media, this study was conducted. From this research it was found that most people use the internet only as social media. Use as a means of supporting economic life ranks only 6 th out of 8 internet use destinations. So it can be concluded that the purpose of using the internet is not yet maximal and it is necessary for the role of local government to help socialize the benefits that can be derived from the existence of internet access in their respective regions, especially the benefits to support the economic needs of the household.
\end{abstract}

Keywords: internet access, five years, information technology, Susenas

\section{PENDAHULUAN}

Diera milenial seperti sekarang ini teknologi informasi dan komunikasi bukan lagi hal yang baru bagi semua orang. Hampir disetiap lini kehidupan kita ada berhubungan dengan teknologi baik didunia pekantoran, sekolah ekonomi dan masih banyak yang lain. Tekonologi informasi dan komunikasi yang berkaitan dengan internet banyak dimanfaatkan salah satunya internet.

"Internet menawarkan alternatif baru dalam memperolehan informasi dan sekaligus penyebarluasan informasi. Jika sebelumnya, informasi berbasis cetak merupakan primadona perpustakaan tradisional, sekarang tersedia format baru dalam bentuk digital melalui Web". (Siregar, 1998). 


\section{Beti}

Dengan adanya internet masyarakat menjadi mudah dalam mengakses apa yang menjadi tujuan pencariannya. Penduduk berumur 5 tahun ke atas yang menggunakan internet di Provinsi Kepulauan Riau sebesar 48,35 \%. (Statistik Kesejahteraan Rakyat Provinsi Kepulauan Riau, 2017). Ini menunjukkan hampir setengah penduduk yang berumur 5 tahun ke atas tahun mengakses internet di Provinsi Kepulauan Riau.

"Kementerian Komunikasi dan Informasi menyebutkan penggunaan internet mayoritas digunakan masyarakat untuk menikmati konten media sosial." (Warta Kepri).

Selain penggunaan internet sebagai media sosial, akan dilihat apakah ada tujuan lain dari penggunaan internet tersebut. Mencari tujuan penggunaan internet sendiri pada penduduk berumur 5 tahun ke atas adalah untuk melihat potensi- potensi apa yang bisa digali dari adanya internet agar keberadaan internet tidak hanya sebagai hiburan tetapi juga dapat meningkatkan taraf hidup masyarakat.

\section{METODOLOGI}

Penulisan karya tulis ilmiah ini menggunakan metode Statistik deskriptif data sekunder hasil survei sosial ekonomi nasional (SUSENAS) tahun 2017.

"Statistik deskriptif atau statistic deduktif adalah bagian dari statistic mempelajari cara pengumpulan data dan penyajian data sehingga mudah dipahami. Statistic deskriptif hanya berhubungan dengan hal mengenai suatu data atau keadaan atau fenomena. Dengan kata statistic deskriftif befungsi menangkan keadaan, gejala atau pesoalan." Hasan ,2001

Data yang digunakan merupakan data hasil olahan survei sosial ekonomi nasional (SUSENAS)bagian teknologi dan Informasi yang pendataannya dilaksanakan pada tahun 2017 di seluruh Kab/Kota di Provinsi Kepulauan Riau dengan banyak sampel 3.332 rumah tangga. Dari 3.332 sampel rumah tangga yang ada diharapkan bisa menggambarkan dari tujuan penggunaan internet pada penduduk berumur 5 tahun keatas di masing-masing Kabupaten/Kota di Provinsi Kepulauan Riau.

\section{HASIL DAN PEMBAHASAN}

Tabel 1. Persentase penduduk berumur 5 tahun ke atas yang mengakses internet menurut Kabupaten/Kota dan Alat yang Digunakan untuk Mengakses Internet

\begin{tabular}{lcc}
\hline \hline & Handphone & $\begin{array}{c}\text { Komputer/ } \\
\text { Laptop }\end{array}$ \\
\hline \multicolumn{1}{c}{$(1)$} & $(2)$ & $(3)$ \\
\hline Karimun & 77.88 & 22.78 \\
Bintan & 78.51 & 21.44 \\
Natuna & 77.23 & 28.22 \\
Lingga & 74.61 & 30.99 \\
Anambas & 71.81 & 35.86 \\
Batam & 84.30 & 12.62 \\
Tanjungpinang & 88.15 & 18.21 \\
\hline \hline
\end{tabular}

Dilihat dari tabel 1 persentase penduduk berumur 5 tahun ke atas di Provinsi kepulauan riau lebih memilih Handphone sebagai alat untuk mengakses internet. Rata-rata persentase setiap kabupaten kota di provinsi kepulauan riau menggunakan handphone sebagai alat untuk akses internet berkisar antara $71 \%$ sampai $89 \%$. Pemakaian computer/laptop sebagai media untuk akses internet persentasenya berkisar antara 18\% sampai 36 persen.

Perbandingan signifikan pemakaian media handphone dengan computer/laptop sebagai alat akses internet terjadi di Kota Batam dan Kota Tanjungpinang. Kabupaten Kepulauan Anambas dengan tingkat akses internet memakai handphone terendah di provinsi Kepulauan Riau yaitu hanya sebesar $71,81 \%$ namun merupakan Kabupaten dengan dengan penggunaan media computer tertinggi sebesar 35,86\% sebagai alat untuk mengakses internet. 


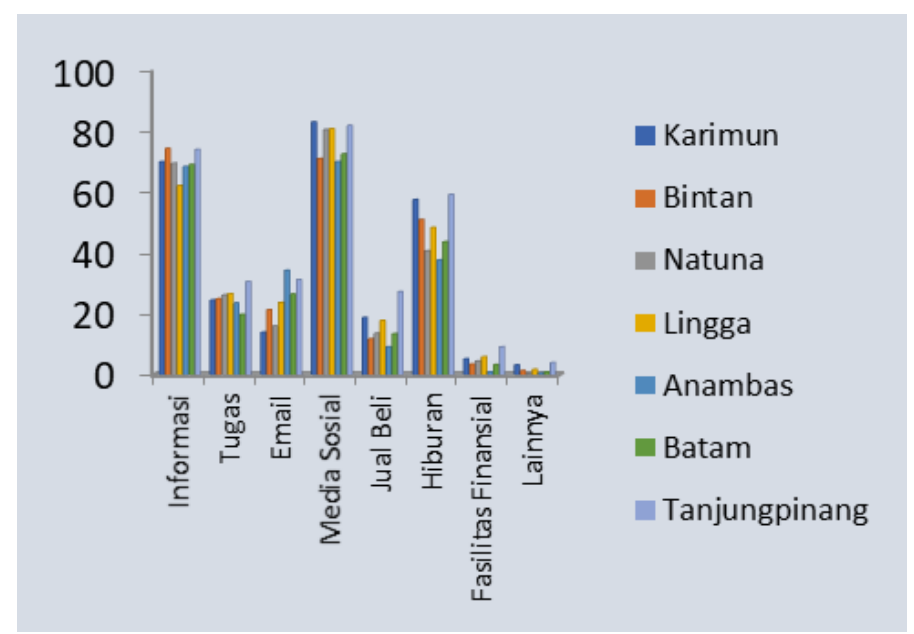

Gambar 1. Persentase penduduk usia 5 tahun ke atas yang mengakses internet menurut Kabupaten /Kota dan tujuan mengakses internet

Tujuan penggunaan internet yang terbanyak adalah sebagai media sosial di masing-masing kabupaten kota di Provinsi Kepulauan Riau dengan kisaran persentase antara 70\% sampai $83 \%$. Hanya kabupaten bintan yang tujuan penggunaan internetnya terbanyak sebagai media informasi dengan persentase $74 \%$. Selain sebagai media sosial penggunaan internet terbanyak kedua adalah sebagai media untuk mencari informasi atau berita. Lebih dai 50\% penduduk di provinsi Kepulauan Riau memanfaatkan internet sebagai media mencari informasi atau berita. Mengerjakan tugas sekolah / kuliah menempati urutan ketiga dengan persentase antara 19\% sampai 26\% masyarakat provinsi kepulauan riau memanfaatkan internet. Batam yang merupakan kota paling maju diprovinsi Kepulauan Riau tetapi merupakan kota yang paling rendah penggunaan internetnya oleh anak- anak angkatan sekolah untuk mencari tugas sekolah atau kuliah. Untuk pemanfaatan internet tertinggi dalam mencari tugas sekolah atau kuliah beada di Kota Tanjungpinang sebesar 30,55\%, diikuti oleh kabupaten Lingga dengan $26.55 \%$.

Selain itu pemanfatan internet dalam kehidupan sehari-hari di provinsi Kepulauan Riau adalah untuk pengiriman email. Kabupaten kepulauan Anambas merupakan persentase tertinggi sebesar 34,20\%. Penggunaan media internet untuk sarana jual beli di Provinsi Kepulauan Riau masih tergolong rendah. Ini dapat dilihat dari persentase penggunaannya di masing-masing kabupaten/kota di Provinsi Kepulaun Riau yang masih berada dibawah angka 20\%. Media internet sebagai hiburan cukup tinggi, rata-rata 37\% - 60\% penggunaannya untuk hiburan.

Fasilitas financial yang mengunakan internet kurang diminati oleh masyarakat di provinsi Kepulauan riau. Persentase penggunaannya hanya berkisar di angka $0.94 \%$ sampai $9 \%$. Hal ini ditunjukkan oleh rendahnya persentase penggunaan internet untuk akses fasilitas financial seperti e-banking.

Melihat tabel dan gambar hasil survei sosial ekonomi nasional ini kecendrungan terbesar setiap kabupaten / kota di Provinsi Kepulauan Riau dalam penggunaan internet masih sebagai media hiburan. Pemanfaatan internet untuk sektor ekomoni belum terlihat. Intrnet sebagai media untk jual/beli pun masih berada diurutan ke 6 terbanyak pemanfaatannya.

Ketersediaan akses internet ini hendaknya dimanfaatkan untuk meningkatkan perekonomian masyarakatnya dan jangan hanya menjadi media hiburan semata. Pemanfaatan yang tetap akan menghasilkan sesuatu yang akan jauh lebih bermanfaat.

\section{KESIMPULAN}

Dengan melihat hasil dan pembahasan bahwa penduduk berumur 5 tahun ke atas di Provinsi Kepulauan Riau lebih banyak mengakses internet untuk tujuan media sosial dan mencari infomasi. Alat yang digunakan untuk mengakses internet yang paling banyak yaitu hanphone dan hanya sebagian kecil yang menggunakan computer/laptop.

Dari gambar 1 kita bisa melihat bahwa pemanfaatan teknologi informasi untuk kegiatan jual/beli masih tergolong kecil. Untuk itu perlu peningkatan pemanfaatan teknologi dan 


\section{Beti}

informasi ini untuk sector pedagangan. Jika pemanfaatan teknologi dan infomasi lebih optimal dalam sector perdagangan (jual/beli) akan dapat meningkatkan perekonomian masyarakat di provinsi Kepulauan Riau.

\section{DAFTAR PUSTAKA}

BPS, 2017, Statistik Kesejahteraan Rakyat Provinsi Kepulauan Riau, Tanjungpinang, Badan Pusat Staistik Provinsi Kepulauan Riau.

Hasan, Iqbal, 2001, Pokok-Pokok Materi Statistik 1 (Statistik Deskriptif), Jakarta: PT. Bumi Aksara

Siregar, Ridwan,1998, Internet: Strategi Penggunaannya di Perpustakaan Perguruan Tinggi,

Library.usu.ac.id, 3 November 2004

Wartakepri ,2016, Mayoritas Penggunaan Internet di Indonesia Hanya Untuk Medsos,https://www.wartakepri.co.id/2016/04/28/mayoritas-penggunaan-internet-diindonesia-hanya-untuk-medsos / 